University of California, Hastings College of the Law UC Hastings Scholarship Repository

1973

\title{
Presumption that Estate Income Is Allocated Among Multiple Beneficiaries in Proportion to Their Receipt of Total Distributions Given Conclusive Rather than Rebuttable Effect
}

Calvin R. Massey

UC Hastings College of the Law, masseyc@uchastings.edu

Follow this and additional works at: http://repository.uchastings.edu/faculty_scholarship

Part of the Estates and Trusts Commons

\section{Recommended Citation}

Calvin R. Massey, Presumption that Estate Income Is Allocated Among Multiple Beneficiaries in Proportion to Their Receipt of Total Distributions Given Conclusive Rather than Rebuttable Effect, 73 Colum. L. Rev. 1319 (1973).

Available at: http://repository.uchastings.edu/faculty_scholarship/508 


\title{
UNIVERSITY of CALIFORNIA HASTINGS COLLEGE OF THE LAW
}

\section{Faculty Publications}

UC Hastings College of the Law Library

\author{
Author: $\quad$ Calvin R. Massey \\ Source: $\quad$ Columbia Law Review \\ Citation: $\quad 73$ Colum. L. Rev. 1319 (1973). \\ Title: $\quad$ Presumption that Estate Income Is Allocated Among Multiple Beneficiaries in \\ Proportion to Their Receipt of Total Distributions Given Conclusive Rather than \\ Rebuttable Effect
}

Originally published in COLUMBIA LAW REVIEW. This article is reprinted with permission from Columbia LAW REVIEW and Columbia University. 


\title{
RECENT DEVELOPMENTS
}

\author{
PRESUMP'TION THAT ESTATE INCOME IS ALLOCATED \\ AMONG MULTIPLE BENEFICIARIES IN PROPORTION \\ TO THEIR RECEIPT OF TO'TAL DISTRIBUTIONS \\ GIVEN CONCLUSIVE RATHER THAN \\ REBUTTABLE EFFECT
}

In 1954 plaintiff Rebekah Harkness' husband died testate, leaving plaintiff one half of his residuary estate. The will further provided that the remaining half, after deduction of all succession taxes applicable to the estate, was to be left in equal shares to four testamentary trusts for the benefit of the children of plaintiff and decedent. Accordingly, the executor of the estate distributed one half of the estate's distributable net income ${ }^{1}$ to plaintiff and an equal amount to the testamentary trusts. The executor also distributed one half of the estate's pre-tax corpus to plaintiff and the remaining half, after payment of all succession taxes on the entire estate, to the testamentary trusts. The result of this distribution was that plaintiff received a total of 76.2907 percent of all distributions, both corpus and income, to the beneficiaries of the residuary estate, comprised of 50 percent of the income generated, and a larger percentage of the remaining corpus of the estate. ${ }^{2}$ Plaintiff included in her 1955 federal income tax return, as income received from her husband's estate, the one half of the estate's distributable net income that she received. ${ }^{3}$ In 1961 , the District Director of Internal Revenue (Manhattan, New York) took the position that plaintiff should have included, as income received from her husband's estate, 76.2907 percent of the distributable net income of the estate, the same percentage as plaintiff's share of the total. ${ }^{4}$ Plaintiff paid the additional tax and interest assessed thereon, filed a timely clain for refund, and, having received no notice of disallowance or refund,

1. INT. REv. CoDE of $1954, \S 643$ (a) defines the term "distributable net income" as "the taxable income of the estate or trust" with certain modifications set forth therein. See Manufacturers Hanover Trust Co. v. United States, 312 F.2d 785, 792-96 (Ct. Cl.), cert. denied, 375 U.S. 880 (1963); Craven, Taxation of Estate and Trust Income Under the 1954 Code, 103 U. PA. L. Rev. 602, 605-08 (1955); Kamin, Surrey \& Warren, The Internal Revenue Code of 1954: Trusts, Estates and Beneficaries, 54 Colum. L. REv. $1237,1240-45$ (1954).

2. Harkness v. United States, 469 F.2d 310, 313 (Ct. Cl. 1972).

3. Id. at 311-12. Corpus distributions are not included in the gross income of the beneficiary by virtue of INT. REv. CODE of 1954, § 102(a) which provides that

Gross income does not include the value of property acquired by gift, bequest, devise or inheritance.

However, income distributions are so included in the gross income of the beneficiary under INT. REv. CODE of 1954, § 102(b)(2) which provides that "[a]ny amount included in the gross income of a beneficiary under subchapter $J$ [trust and estate taxation] shall be treated" as a gift of income from property, to which the exclusion of INT. REv. CODE of $1954, \$ 102(\mathrm{a})$ does not apply.

4. Harkness v. United States, 469 F.2d 310, 311-13 (Ct. Cl. 1972). 
instituted suit to recover such additional tax and interest. 5 In the United States Court of Claims, held, petition dismissed. Relying on section 662(a) (2) (B) of the Internal Revenue Code of 1954 ("Code") ${ }^{6}$ the court concluded that the section creates a conclusive presumption that a beneficiary of a trust or estate receives income from the trust or estate in the same proportion as the total amount distributed to him bears to the total of the amounts distributed to all beneficiaries. ${ }^{7}$ Harkness v. United States, 469 F.2d 310 (Ct. Cl. 1972).

The basic approach of the Code toward taxation of trusts and estates has been labelled the "conduit principle." 8 The essence of the approach is that

a trust or an estate is regarded as a separate taxable entity which computes its tax in essentially the same manner as does an individual taxpayer, except that in addition to the deductions which may be taken by an individual taxpayer the trust [or estate] is granted a deduction for certain amounts distributed or distributable to beneficiaries. The beneficiaries, in turn, include in their income the amount deductible by the trust [or estate]. Other basic features of the conduit principle are that the income distributed by a trust [or estate] retains its tax character in the hands of the beneficiaries and that distributions in excess of the income of the trust [or estate] are not taxable to the beneficiaries but are treated as corpus distributions. $^{9}$

Since distributions of an estate or trust may include distributions of both income and corpus, the Code separates them for tax purposes by defining "distributable net income," based essentially on the taxable income of the estate or trust. ${ }^{16}$ Distributable net income in such cases is the maximum amount that can be treated as a distribution of income, thus setting the amounts that can be included as income to the beneficiaries and that can be deducted from income by the trust or estate. ${ }^{11}$

The distribution rules contained in sections $661-663$ of the Code provide the mechanism for allocating distributable net income both between estate or trust and beneficiaries, and among beneficiaries. Where multiple beneficiaries

5. Id. at 312 .

6. This section provides, inter alia, that if the sum of

all other amounts properly paid, credited, or required to be distributed to all beneficiaries exceeds the distributable net income of the estate or trust, then ... there shall be included in the gross income of the beneficiary an amount which bears the same ratio to distributable net income (reduced by [amounts required to be distributed currently]) as the other amounts properly paid, credited or required to be distributed to the beneficiary bear to the other amounts properly paid, credited, or required to be distributed to all beneficiaries.

7. Harkness v. United States, 469 F.2d 310, 315-17, 321 (Ct. Cl. 1972). Sce note 6 supra.

8. Kamin, Surrey \& Warren, supra note 1 , at 1240.

9. Id. Corpus distributions are excluded from the gross income of the beneficiary by virtue of INT. REv. CODE of 1954, \$ 102 (a). See note 3 supra.

10. Int. REv. CoDE of 1954. See note 1 supra.

11. See Craven, supra note 1, at 607; Kamin, Surrey \& Warren, supra note 1, at 1240. 
exist, the distribution rules specifically allocate income among them. The clistribution method has two objectives: (1) allocation of income between trust and beneficiary in accordance with the conduit principle; and (2) allocation of income among beneficiaries where total distributions of the trust or estate exceed distributable net income. To attain the first objective, section 662 establishes a conclusive presumption that all distributions up to the amount of distributable net income are deemed to be distributions of income to the beneficiaries. ${ }^{12}$ To accomplish the second objective, the section adds another presumption: when all distributions exceed distributable net income, each beneficiary must include in his income that portion of distributable net income that is the same percentage of distributable net income as his percentage of all distributions. ${ }^{13}$ Each beneficiary is thus deemed to receive the same share of both income and corpus. In the instant case, the court concluded that the section contained a conclusive presumption, for whose purposes plaintiff Rebekal Harkness received 76.2907 percent of the estate's distributable net income even though it was uncontested that she had actually received only 50.0 percent. ${ }^{14}$

In its interpretation of the distribution rules the Court of Claims did not distinguish between the two presumptions contained in section 662 and apparently assumed both to be conclusive. ${ }^{15} \mathrm{~A}$ more appropriate method of assessing the effect of section 662 is to separately analyze the legislative intent concerning the two presumptions. The analysis show that the Congress specifically intended only the beneficiary-estate presumption to be conclusive.

Prior to enactment of the distribution rules of the 1954 Code $^{16}$ the $\operatorname{tax}$ law pertaining to distributions of income by estates and trusts was significantly more complex. The 1939 Code $^{17}$

taxed to the beneficiaries only those amounts that were distributed or distributable out of current income. Therefore, distributions which could not be traced to the income of the year of distribution would be taxed to the trust [or estate]. ${ }^{18}$

12. S. Rep. No. 1622, 83d Cong., 2d Sess. 349 (1954).

13. INT. Rev. CoDE of 1954, $\S 662$. The definition of amounts included in this section is so broad that, without qualification, it would render nugatory the exclusion of corpus distributions from income contained in section 102 of the Code. See note 3 and 9 sipra. To preserve this exclusion, section 663 (a) exempts from the distribution rules certain forms of bequests. INT. REV. CODE of 1954, $\$ 663$ (a) excludes from the distribution rules gifts or bequests

of a specific sum of money or of specific property and which is paid or credited

all at once or in not more than 3 installments.

INT. REv. CoDE of 1954, § 663(a) (1). Section 663(a) (2) of the Code excludes charitable deductions qualifying under section $642(\mathrm{c})$. Notable by their absence from these exclusions are bequests of residuary estates, such as are involved in the instant case. Craven, supra note 1, at 613 suggests that the omission of residuary bequests from the section 663 exclusions may have been a drafting oversight.

14. Harkness v. United States, 469 F.2d 310, 315, 317, 321 (Ct. Cl. 1972).

15. Harkness v. United States, $469 \mathrm{~F} .2 \mathrm{~d} \mathrm{310}, 315$ (Ct. Cl. 1972).

16. INT. REv. CODE of 1954, \$\$ 661-63.

17. INT. REv. CoDE of 1939, §§ 162(b), (d), 164.

18. Kamin, Surrey \& Warren, supra note 1, at 1246. 
Several peculiarities resulted from this requirement that distributions be traced to their source. Most notable was the year and a day trust, exemplified by Commissioner v. Dean.19 In Dean a trust was required to distribute its annual income to the beneficiary on January 2 of the following year only if the beneficiary was alive on that date. Because the distribution was conditional upon the beneficiary's survival the distribution was of a prior year and no current income was ever taxable to the beneficiary though it was, of course, taxable to the trust. ${ }^{20}$

To remedy this and related abuses, ${ }^{21}$ Congress passed the Revenue Act of 1942,22 which did not, however, alter the basic concepts of the 1939 Code. Principally, the Act created presumptions that income distributed 65 days prior to or following the taxable year were deemed to be distributions of current income. ${ }^{23}$ These rules partially eliminated the abuses of the Dean trust device but were difficult to understand, hard to apply, arbitrary in result and placed a heavy burden on the taxing authorities to trace the source of distributions to beneficiaries. ${ }^{24}$

With these problems in mind Congress drafted the entirely new distribution rules of the 1954 Code. ${ }^{25}$ In reference to the new presumptions created by section $662(\mathrm{a})$, both the Senate and House Reports noted that

[i]t is thus possible to avoid the necessity for tracing of income which exists generally under the existing law. ${ }^{20}$

It is noteworthy that both reports failed to distinguish between the two entirely different presumptions created by section $662(\mathrm{a})$ and that both emphasized that the intent of Congress was to end abuses relating to allocation of income between a trust or estate and beneficiaries, not allocation among beneficiaries. The reports did not discuss the latter point at all, and it was clearly the demonstration of only the former abuses that caused Congress to act. A conclusive presumption concerning allocation of income among beneficiaries does not, of course, aid the objective of trust-beneficiary allocation, inasmuch as beneficiaries apportion income that has already been allocated to them rather than the trust.

Nothing whatever in the legislative history of section 662 (a) supports the claim that Congress intended to create a conclusive presumption to

19. 102 F.2d 699 (10th Cir. 1939).

20. Id. at 701-02.

21. Sec, e.g., Burnet v. Whitehouse, 283 U.S. 148 (1931), where it was held that income payments in respect to annuities which could be satisfied out of corpus were distributions not taxable to the beneficiaries.

22. 56 Stat. 798, 809 (1942). (1942).

23. INT. REv. CODE of 1939, \& 162(d) and (d) (2), as amended, 56 Stat. 809-10

24. See Kamin, Surrey \& Warren, supra note 1, at 1247-48.

25. INT. REv. CoDE of 1954, §\$ 661-63.

26. H.R. Rep. No. 1337, 83d Cong., 2d Sess. A199 (1954); S. Rep. No. 1622, 83d Cong., $2 \mathrm{~d}$ Sess. 349 (1954). 
govern allocation of income among beneficiaries, although that is what the Harkness court held. That presumption appears to have been added to section 662 with no stated purpose at all. Indeed, giving the presumption conclusive effect may lead to a result directly contrary to the expressed intent of Congress. ${ }^{27}$ The Senate and House Reports on the section indicate an intent that beneficiaries include in their gross income their "proportionate share of . . . distributable net income." 28 The construction given section 662 in the instant case, however, results in a demonstrably disproportionate allocation of the tax burden for distributable net income among beneficiaries.

A strong argument against the conclusive reading can be garnered from judicial interpretation of a comparable section, 661 . Where section 662 defines the income to be declared by beneficiaries of trusts or estates, section 661 allows for the corresponding deduction from gross income allowed the estate or trust in question; both sections contain the presumption that distributions up to the amount of distributable net income are distributions of income. ${ }^{29}$ In Mott $v$. United States, ${ }^{30}$ an estate sought a section 661 deduction from its gross income for testamentary distributions of corpus to a qualified charitable beneficiary. The Court of Claims concluded not only that "sections [661 and 662] should be read together"31 but that

Congress intended to do nothing more than combine the conduit principle with a conclusive presumption that distributions subject to the operation of those sections are distributions of income. ${ }^{32}$

By holding the presumption inapplicable to charitable distributions, ${ }^{33}$ and refusing to permit the income deduction, the Mott court allowed the Government to rebut the supposedly conclusive presumption relating to allocation of income between a trust or estate and beneficiaries. Although application of the presumption would result in treatment of the distribution as income, the Government was allowed to prove that the distribution was in fact of corpus.

Since the court was willing to allow the Government to rebut this presumption, the conclusiveness of which is adequately supported by legislative history, ${ }^{34}$ it makes little sense to refuse to allow taxpayers to rebut the presumption allocating income among beneficiaries. Application of the court's

27. Id. Sec Craven, supra note 1, at 613-14; Fillman, Selections From Subchapter J, 10 TAX L. REv. 453, 470-71 (1955) for additional examples of the inequities due to disproportionate allocation of income among beneficiaries resulting from reading section 662 (a) (2) as creating a conclusive presunption.

28. H.R. Rep. No. 1337, 83d Cong., 2d Sess. A199 (1954) ; S. Rep. No. 1622, 83d Cong., 2 d Sess. 349 (1954) (emphasis added).

29. INT. REv. CoDE of 1954, \$\$ 661-62. To further the conduit principle of the Code, the sections are integrally connected.

30. 462 F.2d 512 (Ct. C1. 1972).

31. Id. at 517 .

32. Id. at $518-19$.

33. Id. at 519 .

34. See text accompanying notes 25-28 supra. 
reasoning in Mott-"that tracing should be allowed in order to prevent injustice and inequity toward the government," 35 despite legislative history supporting a conclusive contrary presumption-would remove the current inequity to the taxpayer. He could trace the distributions and rebut the presumption concerning allocation of income among beneficiaries when necessary to prevent injustice and inequity. ${ }^{36}$ Such a flexible interpretation seems especially desirable given the absence of legislative history indicating a contrary intent. Allowing the taxpayer to rebut the intra-beneficiary allocation presumption would do no violence to the intent of the distribution rules concerning allocation of income between estate or trust and beneficiary. The two presumptions are separate concepts performing separate functions and ought to finally be so recognized and interpreted.

Lastly, the conclusive nature of the intra-beneficiary presumption can be questioned on due process grounds as arbitrary and unreasonable. In Heiner v. Donnan ${ }^{37}$ the Supreme Court held a statutory conclusive presumption that an inter vivos gift within two years of the donor's death is a gift in contemplation of death unconstitutional as a denial of due process. ${ }^{38}$ reasoning that

a statute which imposes a tax upon an assumption of fact which the taxpayer is forbidden to controvert, is so arbitrary and unreasonable that it cannot stand [under due process]. ${ }^{39}$

Heiner, however, came at the forefront of the Supreme Court's "substantive due process" period, when many laws fell because they were termed "arbitrary and unreasonable." 40 Its applicability today is questionable, although Heiner itself continues to be used. In tax cases, however, Heiner is typically cited simply to show the limit beyond which courts cannot go, while the Code provision at issue is usually upheld. The verbal exegesis invoked is that when an assumed fact is deemed "incontrovertible" its use as a basis of taxation is not "arbitrary and unreasonable." 41 Thus a tax on the interest considered inherent in any installment sales contract was upheld, despite the taxpayer's forceful plea that no interest was involved in his particular contract. ${ }^{42}$ That interest would be charged, either in the price of the contract, or as a gift to the purchaser, was held incontrovertible. Generally, it turns out, as the due process

35. Harkness v. United States, 469 F.2d 310, 327 (Ct. Cl. 1972) (Skelton, J., dissenting).

36. Id. at 327 .

37. 285 U.S. 312 (1932).

38. Cf. INT. REv. CODE of $1954, \S 2035$ (b) retaining a rebuttable presumption as to inter vivos gifts within three years of death.

39. Heiner v. Donnan, 285 U.S. 312, 325 (1932).

40. For examples of the application of this doctrine, sec, e.g., Lochner v. New York, 198 U.S. 45 (1905) (nullification of law prescribing maximum hours for work in bakeries) ; Coppage v. Kansas, 236 U.S. 1 (1915) (nullification of law outlawing "yellow" dog" contracts); Adkins v. Children's Hospital, 261 U.S. 525 (1923) (nullification of law setting minimum wages for women).

41. See, e.g., Shanahan v. United States, 447 F.2d 1082, 1084 (10th Cir. 1971).

42. Id. 
clause applies to the tax laws, "Congress is given great leeway. . ."43 Language from another Supreme Court case, Welch v. Henry, ${ }^{44}$ is used to rebut the pervasive implications of Heiner:

Any classification of taxation is permissible which has reasonable relation to a legitimate end of governmental action. ${ }^{45}$

Heiner's greatest continuing vitality is outside the tax area; it is particularly cited with approval in equal protection cases involving fundamental rights, ${ }^{46}$ the so-called "substantive equal protection." For instance, legislative flexibility to employ conclusive presumptions has recently been limited in a series of voter residency cases, which held that where more precise facts of the voter's residence in the state are available, "conclusive presumptions [are] impermissible in light of the individual interests affected." 47 While this may appear to be little more than straightforward substantive due process, its use is as a gloss to equal protection doctrine. Indeed, the Supreme Court has expressly disavowed the former theory, ${ }^{48}$ although it has arguably kept the theory's flexible ability to strike down substantive laws alive through the equal protection cases.

This leaves the constitutionality of section 662 under the due process clause as probably valid. The individual interests affected by section 662 are unlikely to be perceived as so compelling as to justify invocation of the Heiner doctrine, although the strict holding of that decision would probably mandate voiding the section. Certainly the assumed fact of proportionate income distribution among beneficiaries cannot be deemed "incontrovertible." The tax law, however, is riddled with such presumptions, which are designed to minimize $\operatorname{tax}$ avoidance and manipulation and to ease the IRS administrative burden. ${ }^{49}$ Perhaps they are not so much assumed facts at all, but rather fact patterns mandating a prescribed tax treatment, a treatment designed both to encourage subsequent fact patterns, and to minimize abusive ones. The trend of modern cases indicates that a substantive due process challenge to section 662 would probably be dismissed.

In dissenting from the majority holding in Harkness, however, Judge

43. Allen F. Labay, 55 T.C. 6, 15 (1970).

44. 305 U.S. 134 (1938).

45. Id. at 144; relied on in Shanahan v. United States, 447 F.2d 1082, 1084 (10th Cir. 1971).

46. See, c.g., Carrington v. Rash, 380 U.S. 89 (1965) ; Dunn v. Blumstein, 405 U.S. 330 (1972). Despite the proclained demise of substantive due process itself, see note 48 infra and accompanying text, the doctrine seems to be having a nascent resurgence in the area of personal liberties. See Roe v. Wade, 410 U.S. 113, 167 (1973) (Stewart, J., concurring) ; Doe v. Bolton, 410 U.S. 179 (1973) ; Griswold v. Connecticut, 381 U.S. 479 (1965). Cf. Eisenstadt v. Baird, 405 U.S. 438 (1972).

47. Dunn v. Blumstein, 405 U.S. 330, 351 (1972) (emphasis added).

48. See Ferguson v. Skrupa, 372 U.S. 726, 730-31 (1963). Cf. West Coast Hotel Co. v. Parrish, 300 U.S. 379 (1937). 66-67 infra. 
Skelton based his opinion on two other theories that section 662 is unconstitutional and thereby invalid. ${ }^{50}$ His theses do not bear well under close examination, but an analysis of his argument provides a useful understanding of the constitutional validity of such conclusive presumptions under the tax laws. Judge Skelton's theories were: (1) that operation of the provision amounts to a taking of property without due process of law in violation of the fifth amendment $;^{51}$ and (2) that the tax enacted by such a provision is a direct tax unapportioned among the states in violation of Article I, section 9 of the Constitution..$^{52}$

Judge Skelton's due process claim is that in the Harkness situation, a conclusive presumption as to allocation of income among beneficiaries would operate to take property without due process. This argument can be summarily dismissed. The Supreme Court has observed in Magnano Co. v. Hamil$t^{53}$ that

a tax within the lawful power of a state [may not] be judicially stricken down under the due process clause ... unless ... its necessary interpretation and effect be such as plainly to demonstrate that the form of taxation was adopted as a mere disguise, under which there was exercised, in reality, another and different power denied by the Federal Constitution ....54

No such disguise is evident here. The Supreme Court has repeatedly upheld uses of the taxing power for achievement of essentially regulatory or prohibitive objectives. ${ }^{55}$ Likewise, it has repeatedly sustained taxes upon the receipt of property. ${ }^{56}$ 'The due process requirements for the taking of Mrs. Harkness' property have been met.

Judge Skelton's second theory of the unconstitutionality of section 662's

50. Harkness v. United States, 469 F.2d 310, 321-28 (Ct. Cl. 1972) (Skelton, J., dissenting).

51. Id. at 322-23. U.S. Const. amend. V provides, inter alia:

No person shall ... be deprived of life, liberty, or property, without due process

of law; ...

52. Harkness v. United States, 469 F.2d 310, 323-26 (Ct. Cl. 1972) (Skelton, J., dissenting). U.S. ConsT. art. I, \&9 provides, inter alia:

No Capitation, or other direct, Tax shall be laid, unless in Proportion to the Census or Enumeration herein before directed to be taken.

53. 292 U.S. 40 (1934) (upholding a state tax on oleomargarine sales for the purpose of aiding the dairy industry, even though the tax in effect caused appellant to forego selling his product in the state).

54. Id. at 44-45. See Barclay \& Co. v. Edwards, 267 U.S. 442, 450 (1924); Brushaber v. Union Pacific R.R., 240 U.S. 1, $24-26$ (1916); Knowlton v. Moore, 178 U.S. 41, 77 (1900). Contra, Hoeper v. Tax Comm'n of Wisconsin, 284 U.S. 206 (1931); Nichols v. Coolidge, 274 Ư.S. 531 (1927).

55. See Minor v. United States, 396 U.S. 87 (1969) (upholding statutory prohibitions on selling narcotics and marijuana without required forms); United States $v$. Sanchez, 340 U.S. 42 (1950) (upholding a transfer tax of $\$ 100$ per ounce on sales of marijuana to unregistered persons); Sonzinsky v. United States, 300 U.S. 506 (1937) (upholding an annual license fee imposed on firearms dealers). Cf. Gunther \& Dowlina, Cases and Materials on Constitutional LaW 351-66 (8th ed. 1970).

56. See Fernandez v. Wiener, 326 U.S. 340, 352-53 (1945); Knowlton v. Moore, 178 U.S. 41, 78-83 (1900); Scholey v. Rew, 90 U.S. (23 Wall.) 331, 346-48 (1875); Simmons v. United States, 308 F.2d 160, 165-68 (4th Cir. 1962). Cf. N New York Trust Co. v. Eisner, 256 U.S. 345,349 (1921). 
intra-beneficiary conclusive presumption is the claim that the tax is a direct tax unapportioned among the states. ${ }^{57}$ To prove this claim, it must be shown:

that the tax is direct and therefore requires apportionment, and ... that the tax does not fall within the scope of the Sixteenth Amendment which lifts the apportionment requirement from such categories of taxes on income as are deemed to be direct taxes. ${ }^{58}$

A direct tax has been characterized as a tax on property "imposed solely by reason of its being owned by the taxpayer." 59 However, it is settled that "a tax upon the exercise of only some of the rights adhering to ownership,"60 such as upon the transfer of property ${ }^{61}$ or its use, ${ }^{62}$ is an indirect tax that need not be apportioned. A conclusive presumption as to allocation of income among beneficiaries operates to tax the receipt of property. That this does not result in the imposition of a direct tax is pointed out by the Supreme Court in Fernandez $v$. Wiener: ${ }^{33}$

[W] cannot say that there is any want of constitutional power to tax the receipt of [property] ...., whether as a result of inheritance..., or otherwise, whatever name may be given to the tax... Receipt in possession and enjoyment is as much a taxable occasion within the reach of the federal taxing power as the enjoyment of any other incident of property. ${ }^{64}$

Since the section 662 tax is not direct, there is no need to consider whether it falls within the broad exemption of the sixteenth amendment, which allows direct taxes if on income. ${ }^{65}$

57. See note 52 supra.

58. Simmons v. United States, 308 F.2d 160, 166 (4th Cir. 1962). U.S. Const., amend. XVI provides:

The Congress shall have power to lay and collect taxes on incomes, from whatever source derived, without apportionment among the several States, and without regard to any census or enumeration.

59. Simmons v. United States, 308 F.2d 160, 166 (4th Cir. 1962). See Pollock v. Farmers' Loan \& Trust Co., 157 U.S. 429, 580-83, modified on rehearing, 158 U.S. 601, 637 (1895).

60. Simmons v. United States, 308 F.2d 160,166 (4th Cir. 1962).

61. See Fernandez v. Wiener, 326 U.S. 340, 352-55, 361-62 (1945) (estate tax on community property at death of one spouse held valid).

62. See Hylton v. United States, 3 U.S. (3 Dall.) 171 (1796) (tax on carriages for the conveyance of persons held valid).

63. 326 U.S. 340 (1945).

64. Id. at 353. Sce also Scholey v. Rew, 90 U.S. (23 Wall.) 331, 346-48 (1875).

65. It is uncontroverted that "income" as used in the sixteenth amendment does not include principal or corpus. See Taft v. Bowers, 278 U.S. 470, 481 (1929); Eisner v. Macomber, 252 U.S. 189, 206-07 (1920); Richardson v. United States, 294 F.2d 593 (6th Cir. 1961), cert. dented, 369 U.S. 802 (1962); Commissioner v. Obear-Nester Glass Co., 217 F.2d 56 (7th Cir. 1954), cert. denied, 348 U.S. 982 (1955).

This conclusion seems to flow from the judicial insistence

that the word "incomes" in the Sixteenth Amendment should be read in a sense most obvious to the common understanding at the time of its adoption.

Eisner v. Macomber, 252 U.S. 189, 219-20 (1920) (Holmes, J., dissenting). Sec also James v. United States, 366 U.S. 213, 248 (1961) (Whittaker, J., concurring); United States v. Safety Car Heating Co., 297 U.S. 88, 99 (1936); Edwards v. Cuba R.R., 268 U.S. 628, 631 (1925). It appears that the courts view the common usage of "income" to exclude principal. Id. Nevertheless, this point has not been litigated since it is clear that a tax on the receipt of corpus is indirect and thus the exemption of the sixteenth amendment need not be considered. See text accompanying notes 59-64 supra. 
It thus appears that the construction of section $662(a)(2)$ to mandate a conclusive presumption as to allocation of income among beneficiaries would survive constitutional attack, although legitimate doubts may remain as to the constitutionality of such a construction.

Although the legislative history is silent on the intent of section 662 (a) (2) as it relates to distributions among beneficiaries, there are substantial reasons that can be postulated for the provision. First, there is the danger, admitted by the plaintiff in Harkness, that where an estate has principal, current income, and accumulated income, the testator, or the executor, could control the tax consequences to the beneficiaries by making distributions labelled "income" to beneficiaries in lower tax brackets and distributions labelled "principal" to wealthier beneficiaries, thereby reducing the total tax payments. $^{66}$ By fixing the income accruing to each beneficiary, section 662 minimizes such manipulations.

Second, the presumption eliminates legal and other expenses that the taxpayer would incur in tracing and proving income distributions among beneficiaries. To the extent that such expenses might be considered "wasted" in an economic sense since total taxes paid by all beneficiaries would remain relatively constant regardless, the presumption is desirable. Likewise, the provision results in a similar saving for the IRS, both in monetary expenses and in administrative burden. Lastly, it may be argued that the theoretical nature of an estate suggests that income derived during settlement properly should be attached to the corpus from which it is derived. Unlike a trust, an estate involves, in theory at least, the immediate bestowal of the testator's property on his beneficiaries. Settlement of an estate, however, realistically takes years, and income will certainly be generated in the interin. Since the donor's theoretical intent is immediate bestowal of property, income generated prior to actual bestowal can be viewed as income appurtenant to the corpus, income that rightfully belongs to the eventual recipient of the corpus. Such income, of course, should be taxed to the corpus recipient. Thus, it makes sense to presume that any distribution of both corpus and income inclucles distributions of proportionate amounts of income. The logic of such an argument, however, falters when situations are encountered in which such distributions are not made. ${ }^{67}$

Alternatively, sound reasons can be advanced to rebut the above arguments and to support tracing of income as between beneficiaries. First, as has been shown, ${ }^{68}$ Congress never intended to abolish this type of tracing when it enacted the distribution rules of the 1954 Code; it was overtly concerned only with the abuses incident to tracing of income as between trust or estate

66. Harkness v. United States, 469 F.2d 310, 314-15 (Ct. Cl. 1972).

67. See text following note 70 infra.

68. See text accompanying notes 16-28 supra. 
and beneficiary, not among beneficiaries. To abolish tracing among beneficiaries by giving conclusive effect to the presumption as to allocation of income among beneficiaries is either to ignore legislative intent or to assume that the legislators were concerned only about "abuses," no matter what form they may take. This latter assumption will not bear close scrutiny, for if this were the case, Congress would not have enacted, at the same time, a provision that gives the beneficiaries of trusts the tracing benefits denied in Harkness to beneficiaries of residuary estates. ${ }^{69}$ While Congress may well be able to legislate a conclusive presumption allocating income among beneficiaries, it should not do so unintentionally, without explicitly recognizing and evaluating the consequences of its act. In any case, the danger of manipulation of tax consequences among beneficiaries may be exaggerated. In any large estate, even if an indigent beneficiary were given only income, he would likely retain a significant tax burden. Income generated by an estate during settlement will almost always remain the smallest part of the eventual distribution.

Second, some states, such as New York, have laws mandating proportionate distributions of incone earned during the pendency of an estate among beneficiaries unless the testator otherwise provides. ${ }^{70}$ The effect of Harkness, however, is to penalize the beneficiaries of a testator who does so otherwise provide, by taxing them as though he had not. It is undesirable for the federal tax law to so undercut a will made in conformity with the applicable state law. A rebuttable presumption allowing tracing would eliminate the problem.

Third, widespread application of Harkness will result in unjust taxation. During the pendency of an estate it is not uncommon for income to be earned that is not divided among beneficiaries strictly proportionally to corpus. The situation may be as in Harkness where the income earned by the monies eventually used to pay death taxes goes to only one group of beneficiaries. This "bonus" income seems to have been ignored by Congress in formulating its presumption, but must be a recurrent situation. Or, it may be that all beneficiaries receive the income generated by that portion of the corpus that they are willed, but the income thus generated is not proportional to the share of the corpus received. For instance, one beneficiary may receive undeveloped real property that is currently generating no income, while another may receive high yield bonds along with substantial interim income. Or, the testator may have specifically provided for non-proportionate distribution of income.

69. INT. REv. CoDE of $1954, \S 663(\mathrm{c})$, the "separate share" provision. Sce notes 7476 infra.

70. See N.Y. Pers. Prop. Law § 17-b (McKinney 1962), which provides, inter alia:

Unless otherwise expressly provided by the will of a person dying after this act takes effect, all income from real and personal property earned during the period of administration of the estate of such testator and not payable to others or otherwise disposed of by the will shall be distributed pro rata as income among the beneficiaries of any trust created out of the residuary estate of such testator and the other persons entitled to such residuary estate. 
In any of these cases, the beneficiaries would still be conclusively deemed by section 662 to have received a proportionate share of the income that was distributed. In such situations, some beneficiaries will inevitably be taxed on income they did not in fact receive, and some will receive windfall income on which they are not taxed. The inequity of such taxation must be balanced directly against the inequity of inevitable tax manipulation that would follow if tracing were allowed.

Lastly, there are the possible constitutional problems with a conclusive interpretation. Since courts generally try to avoid statutory interpretations that raise doubts as to constitutionality, ${ }^{71}$ it may be preferable to interpret the presumption to be rebuttable. Such an interpretation would not be difficult given the often inequitable results of section 662 , the lack of legislative intent, the Mott case, and the possible constitutional doubts. Rebuttable presumptions are constitutionally permissible if there is simply a "rational connection" between the proved and assumed facts, ${ }^{72}$ a test section 662 could surely meet. ${ }^{73}$

But preferable to judicial interpretation would be legislative action. Congress should face the implications of its action, and, if persuaded by the arguments above, enact remedial legislation. One remedial approach would be to include estates in the separate share provision of section $663(\mathrm{c}) .^{74}$ This rule, now applicable only to trusts, provides that, for the sole purpose of determining the amount of clistributable net income which is taxable to a beneficiary, where a single trust has multiple beneficiaries, substantially separate and independent shares of different beneficiaries are to be treated as separate trusts. ${ }^{75}$ Under this approach, Mrs. Harkness' half of the estate and her half of the income generated would have been separated from the four trusts. She would only have been taxed on income actually received. Several drafts of the that

71. See Blodgett v. Holden, 275 U.S. 142 (1927) where Justice Holmes concluded

as between two possible interpretations of a statute, by one of which it would be unconstitutional and the other valid, our plain duty is to adopt that which will save the Act. Even to avoid a serious doubt the rule is the same.

Id. at 148; Lewis v. White, 56 F.2d 390, 392 (D. Mass. 1932).

72. The "rational connection" test is expounded in Tot v. United States, 319 U.S. 463, 467-68 (1942). Sce also Turner v. United States, 396 U.S. 398, relicaring devied, 397 U.S. 958 (1970); Leary v. United States, 395 U.S. 6 (1969); United States v. Romano, 382 U.S. 136 (1965); United States v. Gainey, 380 U.S. 63 (1965); Note, The Unconstitutionality of Statutory Criminal Presmmptions, 22 STAN. L. Rev. 341 (1970).

73. See text preceding note 67 supra.

74. See INT. REv. CoDE of 1954, \& 663 (c).

75. INT. REv. CODE of $1954, \S 663$ (c). The separate share rule is administered according to Treasury Regulations; Treas. Reg. \& 1.663(c)-1-4 (1972). The Senate Report on this provision, while it was being considered by the Congress, indicates its purpose:

The effect of this provision is to prevent a beneficiary from being subjected to tax on a distribution which represents a corpus distribution as to him but which would, except for this provision, be treated as a taxable distribution, since the trust income is being accumulated for another beneficiary to whom it will ultimately be made available.

S. REP. No. 1622, 83d Cong., 2d Sess. 355 (1954). 
1954 Code included estates in the separate share provision and it is possible that statutory exclusion resulted from legislative oversight. ${ }^{76}$ Commentators have termed the exclusion of estates from the provision "inequitable"77 and inclusion of estates would immediately remedy the unjust, and possibly unintended, result of the instant case.

A second possible legislative remedy is amendment of section $662(a)(2)$ of the Code specifically to allow taxpayers to rebut the presumption concerning allocation of income among beneficiaries. Such a step would not contravene the intentions or operation of the distribution rules ${ }^{78}$ and would introduce much needed clarity into the administration of the subsection.

In the end, the major reason for retaining the conclusive presumption is to prevent likely, although possibly minimal, tax manipulation. Balanced against the inequitable tax imposed to prevent the abuse, however, the cure may be seen to do more harm than the disease. Whether by judicial construction or by legislative enactment, the Harkness result should be made a momentary aberration in the application of the tax laws. Section 662's conclusive presumption allocating income among beneficiaries for tax purpose serves little useful purpose; it should be eliminated.

Calvin R. Massey

\section{JUVENILE DEFENDANT IN FEDERAL SYSTEM NOT ENTITLED TO COUNSEL OR HEARING AT TIME DETERMINATION IS MADE BY THE ATTORNEY GENERAL TO PROCEED AGAINST HIM AS AN ADULT}

Appellant Earl French Cox, Jr., was charged, with four others, with bank robbery. Since Cox was seventeen years old at the time of his offense, he was subject to the special statutory provisions and procedures applicable to juvenile defendants tried in federal courts. ${ }^{1}$ Pursuant to 18 U.S.C. $\S 5032,{ }^{2}$ however, the United States Attorney submitted a written request to the Attorney General for permission to prosecute Cox as an adult offender rather than as a juvenile. In support of his request, the U.S. Attorney reported that there

76. See Kamin, Surrey \& Warren, supra note 1 , at $1258 \mathrm{n} .51$ where it is noted that estates were included in the separate share provision in both the A.L.I. and A.B.A. drafts of the 1954 Code.

77. See Craven, supra note 1, at 616. See also Kamin, Surrey \& Warren, supra note 1, at 1258-59; Holland, Kennedy, Surrey \& Warren, A Proposed Revision of the Federal Income Tax Treatment of Trusts and Estates-American Law Institute Draft, 53 Colum. L. Rev. 316, 345-48 (1953).

78. INT. REv. Code of 1954, $\$$ 661-63. See text following note 35 supra.

1. 18 U.S.C. $\S \S 5031-5034$ (1970). See notes 15-19 infra and accompanying text.

2. See text accompanying notes 15-19 infra. 
were other serious charges pending against $\operatorname{Cox}^{3}$ and that Cox appeared to be the instigator of the robbery. He added that, since prosecution as a juvenile leads to different and less onerous consequences than do adult proceedings, particularly with respect to length of sentence, ${ }^{4}$ it seemed inequitable to try Cox as a juvenile, while trying his co-defendants as adults. ${ }^{5}$ The Attorney General authorized the U.S. Attorney to proceed against Cox as an adult, stating, however, that the U.S. Attorney might wish to suggest to the court a sentence under the Federal Youth Correction Act, which provides for special sentencing treatment of certain youthful offenders. ${ }^{6}$

Cox waived formal indictment, pleaded guilty to a criminal information charging that he had committed an armed bank robbery, and was sentenced to imprisonment for a term of fifteen years. Cox challenged his conviction on the grounds that the determination of the United States Attorney and the Attorney General to proceed against him as an aduit was unconstitutional in that (1) at the time of the decision he lacked counsel and was not advised that he had a right to counsel, (2) the decision was not made in accordance with due process, and (3) the decision was arbitrary and capricious.

The district court held that the right to counsel did not attach at the time the Attorney General's determination was made, and consequently denied relief. On appeal, the Fourth Circuit reversed, holding that at the time of the Attorney General's determination, Cox had not only a right to counsel, but also a right to notice of the request of the U.S. Attorney to the Attorney General with the U.S. Attorney's reasons for requesting adult prosecution and the supporting data, and a right to an opportunity to submit additional

3. At the time of the request, there were charges pending against Cox for housebreaking, attempted grand larceny, and armed robbery. Cox v. United States, 473 F.2d 334,335 (4th Cir. 1973) (rehearing en banc).

4. See notes $42-43$ infra and accompanying text.

5. Since the four other participants were all over eighteen years of age, they were ineligible for juvenile treatment and instead were prosecuted as adults.

6. Under the Federal Youth Corrections Act, 18 U.S.C. \$ 5005 et seq. (1970), a youth offender, defined as a person under the age of twenty-two years at the time of conviction, is subject to a variety of sentencing alternatives upon his conviction. If the sentencing judge feels the offender does not need commitment he may suspend the imposition of sentence and place the youth on probation. Alternatively, the judge niay order, in lieu of the sentence provided by law, a commitment of indeterminate duration in special youth corrections institutions. In such instances, the youth must be conditionally released from the institution within four years of commitment and may be unconditionally released one year after his conditional release. In any event, the youth shall be unconditionally released not later than six years from the date of his conviction. Should the sentencing judge determine that the youth needs more than six years to achieve rehabilitation, he may order the youth committed to a corrections jistitution for a period not to exceed the maximum period otherwise provided by law for the underlying substantive offense. Upon successful completion of the youth's commitment under either sentencing scheme, and upon his release prior to the expiration of the maximum term, the record of his offense is expunged. Finally, the sentencing judge has the option to disregard the Act's provisions and sentence a youth offender as an adult, if he determines that the youth will not derive benefit from the special treatment afforded by the Act. For a decision greatly limiting the judge's discretion to ignore the Act and providing for appellate review of the judge's decision to sentence a youth offender as an adult, see United States v. Coefield, 476 F.2d 1152 (D.C. Cir. 1973). 
data to the Attorney General to rebut the request. On rehearing, en banc, held, reversed. Since the Attorney General's election to proceed against a juvenile as an adult is a prosecutorial decision to which the due process clause of the fifth amendment is inapplicable, there is no right to a hearing or to counsel when such decision is made. Cox v. United States, 473 F.2d 334 (4th Cir. 1973) (rehearing en banc).

Cox v. United States appears to be the first case in which the court's attention was focused upon the issue of a juvenile defendant's right to hearing and counsel as a part of the Attorney General's decision to proceed against him as an adult. ${ }^{7}$ The Fourth Circuit approached the issue by considering comparisons of the delegation of discretion to the Attorney General to (a) a judicial waiver of jurisdiction by a juvenile court in a state proceeding, in which case the right to notice and hearing would apply, ${ }^{8}$ and (b) a prosecutorial decision, in which case the due process guaranty of hearing would not be applicable. The court, upon rehearing en banc, concluded that the latter characterization was more appropriate, and denied relief. It is posited, however, that whatever formal characterization may be adopted, the underlying problem is not finally resolved by the process of choosing between alternative labels of indeterminate accuracy and applicability. Rather, the decision whether to grant a juvenile defendant the right to a hearing and to counsel to contest the Attorney General's election to proceed against him as an adult must be made by looking to the rationale which underlies the differentiation between adult and juvenile proceedings.

The existence of special provisions for juveniles originated with a legislative desire to deal with youthful offenders in a manner maximizing the rehabilitative purposes of the correction scheme and minimizing the adversarial

7. Pursuant to 18 U.S.C. $\S 5032$ (1970). The Southern District of New York twice held, although only tangentially without discussion or analysis, that the discretion of the Attorney General provided by this section is absolute. Ramirez v. United States, 238 F. Supp. 763 (S.D.N.Y. 1965); United States v. Verra, 203 F. Supp. 87 (S.D.N.Y. 1962). The paucity of decisions in this area may be attributable to the existence of a general federal policy of turning juveniles over to state authorities. In writing of his personal experiences in California, one commentator has suggested that this policy is based "partly on the theory that the conduct of its youth was primarily a state responsibility and partly because [California] was generally conceded to have better facilities for juvenile correction than the federal government." Kaplan, The Prosecutorial Discretion-A Comment, 60 Nw. U.L. REv. 174, 191 (1965).

8. The Fourth Circuit had previously upheld the right to counsel and limited hearing in state waiver proceedings in Kemplen v. State, 428 F.2d 169 (4th Cir. 1970). In Kemplen, the court was concerned with a waiver of juvenile jurisdiction under a Maryland statute which permitted a state juvenile court to waive its jurisdiction and thus permit a juvenile to be tried and sentenced as an adult. In deciding that Kemplen was entitled to counsel at the waiver hearing, the court relied principally upon Kent v. United States, 383 U.S. 541 (1966), and In re Gault, 387 U.S. 1 (1967), see notes 20-30 and accompanying text infra. In addition, the court held that the right to counsel attached since for Kemplen, waiver was a critical stage in the proceedings against him-prosecution and conviction as an adult could lead to an active prison sentence and permanent criminal record, whereas conviction as a juvenile would merely result in commitment to a training school for rehabilitation. See 428 F.2d at 174 . 
elements which characterize adult criminal proceedings. ${ }^{9} \mathrm{~A}$ juvenile proceeding was, theoretically, one in which the state, the court, and its officers were engaged in a cooperative effort to "provide measures of guidance and rehabilitation for the child and protection for society, not to fix criminal responsibility, guilt and punishment." 10 Because the state was viewed as acting in parcns patriae, juvenile proceedings were viewed as civil rather than criminal in nature, and many of the procedural rights accorded adults in criminal proceedings were withheld from juveniles. ${ }^{11}$

In both the state and federal systems, provision is made for proceeding against a juvenile as an adult in certain situations. In the state context, the statutory scheme typically allocates primary juriscliction over proceedings involving juvenile offenders to a juvenile court which is responsible for determining whether or not the juvenile's behavior justifies his being classified as a delinquent. The juvenile court, however, may waive its jurisdiction, in which case jurisdiction devolves upon the general trial court, where the juvenile may be treated as an adult charged with a substantive offense. ${ }^{12}$

In the federal system, there are no separate juvenile courts; rather, the district courts have jurisdiction to try juveniles, ${ }^{13}$ defined to be persons who have not attained their eighteenth birthday. ${ }^{14}$ The federal statute provicles:

A juvenile alleged to have committed one or more acts in violation of a law of the United States not punishable by death or life imprisonment, and not surrendered to the authorities of a state, ${ }^{15}$ shall be proceeded against as a juvenile delinquent if he consents to such procedure, ${ }^{16}$ unless the Attorney General, in his discretion, has expressly directed otherwise.

In such event, the juvenile shall be proceeded against by in-

9. See In re Gault, 387 U.S. 1, $15-17$ (1967) ; Kent v. United States, 383 U.S. 541, 554-55 (1966) ; see generally Handler, The Juvonile Court and the Adversary System: Problems of Function and Form, 1965 Wrs. L. Rev. 7; Mack, The Juvenile Court, 23 Harv. L. Rev. 104 (1909) ; Note, Juvenile Delinquents: The Policc, State Courts, and Individualized Justice, 79 HARV. L. REv. 775 (1966).

10. Kent v. United States, 383 U.S. 541, 554 (1966).

11. For example, it has been held that a juvenile is not entitled to bail, to indictment by grand jury, to a speedy and public trial, or to trial by jury. Sec Pee v. United States, 274 F.2d 556 (D.C. Cir. 1959); Paulsen, Fairness to the Jitr'cnile Offender, 41 MinN. L. REv. 547 (1957). Moreover, prior to In $r e$ Gault, 387 U.S. 1 (1967), it had been held that the juvenile was not entitled to counsel, to immunity against self-incrimination or to confrontation of his accusers. Sec generally Paulsen, supra.

12. For example, such a statutory scheme exists in Maryland and provided the basis for the decision in Kemplen v. State, 428 F.2d 169 (4th Cir. 1970). Sec note 8 supra.

13. 18 U.S.C. \& $5033(1970)$.

14. 18 U.S.C. \& $5031(1970)$.

15. See note 7 supra.

16. Juvenile proceedings are non-jury, and the juvenile's consent to such proceeding constitutes a waiver of a trial by jury. The consent must be given in writing before a federal district judge, who must apprise the juvenile of the consequences of his consent. Cf. McKeiver v. Pennsylvania, 403 U.S. 528 (1971) in which a divided Court held that trial by jury in the state juvenile court's adjudicative stage is not a constitutional requirement. 
formation and no criminal prosecution shall be instituted for the alleged violation. ${ }^{17}$

If the district court finds a juvenile to be delinquent, special penalties may be imposed. ${ }^{18}$ The juvenile may be placed on probation for a period not exceeding his minority, or be committed to the custody of the Attorney General for a like period-but not exceeding the term which might be imposed had he been tried and convicted as an adult. If the juvenile is committed to the custody of the Attorney General, the latter is authorized "to designate any public or private agency or foster home for the custody, care, subsistence, education and training of the juvenile during the period for which he is committed."19

Despite the original promulgation of the juvenile system for beneficent and compassionate purposes, there has been increasing recognition that the discontinuity between the adult and juvenile systems has, in practice, often worked great hardship on the juvenile. ${ }^{20}$ This factor greatly influenced the decision in Kent $v$. United States ${ }^{21}$ in which the Supreme Court considered the requirements for a valid waiver of the "exclusive" jurisdiction of the Juvenile Court of the District of Columbia so that a juvenile could be tried in the adult court of the District. ${ }^{22}$ The Court recognized that

[t] here is evidence, in fact, that there may be grounds for concern that the cbild receives the worst of both worlds: that he gets neither the protections accorded to adults nor the solicitous care and regenerative treatment postulated for children. ${ }^{23}$

In an attempt to remedy the problem, the Court held in Kent that, in a waiver proceeding, the juvenile has a right to a hearing prior to entry of the waiver order, to counsel who may see the child's social records, submit materials helpful to the child, and challenge or impeach any material submitted by the court's staff, and to a statement by the Juvenile Court of the reasons for its decision.

17. 18 U.S.C. \$ 5032 (1970).

18. 18 U.S.C. \$ 5034 (1970).

19. Cox v. United States, 473 F.2d 334, 339 (4th Cir. 1973) (rehearing en banc).

20. See In re Gault, 387 U.S. 1, 17-19 (1967). See also Handler, supra note 9, and Note, supra note 9.

21. 383 U.S. 541 (1966).

22. The District of Columbia has its own Juvenile Court Act, separate from the federal provisions, which, like most state statutory schemes, provides for a separate juvenile court system. The provision under consideration in $K e n t$ was as follows:

If a child sixteen years of age or older is charged with an offense which would amount to a felony in the case of an adult, or any child charged with an offense which if committed by an adult is punishable by death or life imprisonment, the judge may, after full investigation, waive jurisdiction and order such child held for trial under the regular procedure of the court which would have jurisdiction of such offense if committed by an adult; or such other court may exercise the powers conferred upon the juvenile court in this subchapter in conducting and disposing of such cases.

D.C. CodE ANN. \& 11-1553 (Supp. IV, 1965). In 1970, the D.C. Code was amended to reflect the Kent decision. For the parallel provision to the one cited above, see D.C. ConE ANN. \& 16-2307 (Supp. V, 1972). 23. 383 U.S. 541,556 (1966). 
Although the Kent decision rested on statutory rather than constitutional grounds, ${ }^{24}$ the Court hinted that its reasoning need not be so confined:

[In determining] the "critically important" question whether a child will be deprived of the special protections and provisions of the Juvenile Court Act ... there is no place in our system of law for reaching a result of such tremendous consequences without ceremony-without hearing, without effective assistance of counsel, without a statement of reasons. It is inconceivable that a court of justice dealing with adults, with respect to a similar issue, would proceed in this manner. It would be extraordinary if society's special concern for children, as reflected in the District of Columbia's Juvenile Court Act, permitted this procedure. We hold that it does not. . . ${ }^{25} \mathrm{We}$ believe that this result is required by the statute read in the context of constitutional principles relating to due process and the assistance of counsel. . $^{2}$

Shortly thereafter, the Supreme Court recognized the constitutional backdrop against which it had reasoned in Kent. In In re Gault, ${ }^{27}$ the Court recalled:

Although our decision [in Kent] turned upon the language of the statute, we emphasized the necessity that "the basic requirements of due process and fairness" be satisfied in such [waiver] proceedings. ...

[While Kent and other cases] relate only to restricted aspects of the subject, they unmistakably indicate that, whatever may be their precise impact, neither the Fourteenth Amendment nor the Bill of Rights is for adults alone. ${ }^{28}$

Moreover, the Gault decision, which extended certain constitutional rights to juvenile defendants, ${ }^{29}$ rested in part on Kent. ${ }^{30}$ Such reliance in a purely constitutionally-based decision forestalls any interpretation of Kent as merely statutorily-derived rulemaking.

But in Cox the Fourth Circuit ignored the hint in Kent, and the firmer constitutional underpinnings added by Gault, that the protections accorcled to juvenile defendants in proceedings involving the waiver of state juvenile court jurisdiction are constitutionally guaranteed and mandated in the federal

24. See id.

25. Id. at 553-54.

26. Id. at 557 (emphasis added).

27. 387 U.S. 1 (1967). In Gault, the Court held that in juvenile proceedings, due process requires proper notice of specific allegations of misconduct be given to the child and his parents to allow adequate opportunity to prepare a defense, that child and parent must be advised of the right to counsel, that the constitutional privilege against selfincrimination applies, and that absent a valid confession, the child must have an opportunity to confront and cross-examine witnesses. The Court was careful to limit the scope of its opinion to "the proceedings by which a determination is made as to whether a juvenile is a 'delinquent' as a result of alleged misconduct on his part, with the consequence that he may be committed to a state institution." Id. at 13. Gault thus does not directly apply to the Cox situation.

28. Id. at 12-13.

29. See note 27 supra.

30. See 387 U.S. 1, 30-31 (1967). 
context as well. Instead, the en banc court ruled that because the federal statutory scheme grants the jurisdictional decision to an executive rather than a judicial officer, the Kent protections are inapplicable. The court tried to minimize the similarity in the waiver decisions, whether made by the Attorney General or by a juvenile court, by suggesting that simply because the effect of both decisions is the same, the character of the proceedings need not be. ${ }^{31}$ Analysis of both procedures in light of Kent, however, suggests that it is not simply the effect of the procedures that is identical. Rather, the factors influencing the respective decisions are the same; the only valid distinction is that in one case the legislature has entrusted the decision to an executive, in the other to a court.

The crux of the Kent opinion is the Court's recognition that the decision to prosecute a juvenile as an adult is 'a 'critically important' action determining vitally important statutory rights of the juvenile."32 In requiring that procedural safeguards be available to the juvenile at the time this decision is made, the Court analyzed the implications of five factors: (1) the relationship between the legislative purpose and the statutory scheme; (2) the extent of permissible discretion; (3) the standards provided for the decision-maker; (4) the differential consequences of adult and juvenile proceedings; and (5) the danger of ex parte decision-making. The Court's analysis of these factors in Kent would seem equally applicable in the federal context.

1. Purpose. The District of Columbia statute construed in Kent and the federal statute have a common purpose: both were designed to provide special benefits and protections for the juvenile. ${ }^{33}$ Moreover, in both cases, it is clear that juvenile, non-criminal treatment was to be the rule, and adult, criminal treatment the exception. ${ }^{34}$ This preference for the imposition of the more lenient juvenile treatment was found by Kent to be implicit in the District of Columbia statute from its vesting of "original and exclusive jurisdiction" over the child in the Juvenile Court. ${ }^{35}$ In the federal statute the construction is simpler ; the preference is explicit in the text. ${ }^{36}$

2. Discretion. In Kent the Court construed the D.C. statute to grant the Juvenile Court judge a substantial degree of discretion in deciding whether

31. Cox v. United States, 473 F.2d 334, 336 (4th Cir. 1973) (rehearing en banc).

32. 383 U.S. 541, 556 (1966). Although the Court relied in part on prior District of Columbia decisions, Black v. United States, 355 F.2d 104 (D.C. Cir. 1965); Watkins v. United States, 343 F.2d 278 (D.C. Cir. 1964), it is relatively clear that the Court would have reached the same conclusion independently. See 383 U.S. at 560 .

33. Compare 383 U.S. at 556-57, with S. ReP. No. 1989, 75th Cong., 3d Sess. (1938).

34. See 383 U.S. at 560-61, citing Harling v. United States, 295 F.2d 161, 164-65 (D.C. Cir. 1961).

35. D.C. Code ANN. § 11-1551 (Supp. IV, 1965), as amended, D.C. Code ANn. § 11-1101 (Supp. V, 1972). See 383 U.S. at 543 .

36. "A juvenile... shall be proceded against as a juvenile delinquent if he consents to such procedure unless the Attorney General, in his discretion, has expressly directed otherwise." 18 U.S.C. \& 5032 (1970) (emphasis added). Cf. S. REP. No. 1989, 75th Cong., 3d Sess. (1938). 
to waive jurisdiction. ${ }^{37}$ Despite this latitude, however, the Court held that the Juvenile Court may not determine the "critically important" question of whether the child will be deprived of the special protections and provisions of the Juvenile Court Act without the active participation of the child's representative. $^{38}$ The federal statute expressly grants the Attorney General the discretion to proceed against a juvenile as an adult. ${ }^{30}$ Nothing on the face of the federal statute suggests that the Attorney General should have any more freedom to act than the D.C. juvenile court judge, and such a distinction makes little sense since both officers are deciding essentially the same issue: whether a juvenile should be subjected to adult criminal procedures.

3. Standards Provided. The D.C. Juvenile Court Act allows waiver of juriscliction only after "full investigation." 40 The Kent Court noted that while this provision stated the general circumstances of age and type of offense under which a child may be held for trial under adult procedures, it did not indicate the type of information a "full investigation" might reveal to justify that decision. ${ }^{41}$ Rather, the legislature left the formulation of stich criteria to the juvenile court judge. ${ }^{42}$ Emphasizing the critical importance of the waiver decision and the impossibility of meaningful judicial review without a statement of the reasons motivating the waiver, ${ }^{43}$ the Court instructed the Juvenile Court to henceforth accompany any waiver order with a statenent of reasons and underlying facts "sufficient to demonstrate that the statutory requirement of 'full investigation' has been met . . .".44 The Court attached to the decision a policy memorandum which had been formulated, but then rescinded, by the Juvenile Court to guide its waiver decisions. ${ }^{45}$ The memorandum set forth "criteria and principles concerning waiver of jurisdiction which are consistent with the basic aims and purposes of the Juvenile Court Act." 46 It placed an affirmative duty upon the decision-maker's staff to develop fully all information relevant to the judging criteria, and a like duty on the decision-maker to consider all relevant factors before reaching a waiver

37. 383 U.S. at $552-53$.

38. Id. at 553 .

39. 18 U.S.C. $\$ 5032$ (1970).

40. D.C. CODE ANN. § 11-1553 (Supp. IV, 1965). See note 22 supra.

41. 383 U.S. at 547.

42. $I d$. at 566 .

43. Id. at $560-61$.

44. Id. at 561 .

45. Id. at 546 n. 4 .

46. Id. at 565-68. In this policy memorandum the Juvenile Court listed the following determinative factors which the judge should consider in deciding whether to waive the Juvenile Court's jurisdiction: (1) The seriousness of the alleged offense to the community. (2) Whether the offense was violent, willful, or premeditated. (3) Whether the offense was against persons or against property. (4) The prosecutive merit of the complaint. (5) The desirability of trial and disposition of the entire offense in one court when the juvenile's associates in the offense are adults. (6) The sophistication and maturity of the juvenile. (7) The record and previous history of the juvenile. (8) The prospects for adequate protection of the public and the likelihood or reasonable relabilitation of the juvenile. Id. at 566-67. 
decision. ${ }^{47}$ In 1970 , the basic themes of the memorandum-specific criteria for judgment with a concomitant duty to consider them-were enacted into positive law in the District of Columbia. ${ }^{48}$ The current federal statute remains devoid of specific standards, providing only that the Attorney General may, in his discretion, direct adult proceedings. ${ }^{49}$ But the discretionary act performed by the Attorney General in the federal scheme affects the juvenile in a manner similar to the judicial waiver of jurisdiction at issue in Kent. Since the decision-maker's discretionary action is as important to the juvenile defendant in the federal scheme as it is in the D.C. Juvenile Court Act, under the Kent rationale it would seem equally incumbent on the federal system to state reasons for the exercise of discretion, and to allow judicial review of the decision.

4. Differential Consequences. In Kent, the Court emphasized that its decision requiring procedural safeguards in waiver proceedings was dictated by the disparate consequences of convictions under juvenile and adult proceedings. ${ }^{50}$ This disparity is equally evident in the federal system. In both the Kent and the Cox fact situations, there was an enormous difference between adult and juvenile proceedings in the lengths of possible sentence. In Kent, where defendant was charged with housebreaking, robbery and rape, adult proceedings exposed him to the possibility of a death sentence instead of rehabilitative treatment for a maximum of five years until he attained his majority. In Cox, where defendant was charged with bank robbery, adult proceedings led to imposition of a sentence of fifteen years, rather than a maximum of the four years until he reached twenty-one. The type of facility in which defendant would serve his term also varies depending on the type of proceeding; adult proceedings result in incarceration in prison, while juvenile proceedings lead to detention in a rehabilitative center, or possibly a foster home. In addition, in contrast to adult proceedings, juvenile proceedings afford defendant protection against some consequences of adult conviction such as the loss of certain civil rights, the use of the prior conviction to impeach the adult in any subsequent proceeding, and disqualification for public employment. ${ }^{51}$

47. Id. at 567-68.

48. D.C. CODE ANN. \$ 16-2307 (Supp. V, 1972).

49. See text accompanying notes 16-17 supra. Nor are standards set forth in the legislative history of the statute. S. REP. No. 1989, 75th Cong., 3d Sess. (1938). The stated purpose of the provision was to provide a means of prosecuting more serious offenders in the same manner as adults "if it appears desirable." Id. at 2.

50. 383 U.S. at $556-57$.

51. See id. at 557; D.C. CoDE ANN. §§ 11-1551, 16-2307, 16-2308, 16-2313, 11-1586 (Supp. IV, 1965). The pertinent amendments to these sections can be found in D.C. CODE ANN. §§ 16-2313, 16-2316, 16-2318, 16-2328 and 16-2330 to 2335 (Supp. V, 1972). Disparities in consequences of juvenile and adult proceedings may be mitigated, but not completely erased, by the availability of the Federal Youth Offender Act which provides a preferred sentencing alternative for juveniles proceeded against as adults. The relief provided is not certain. The juvenile may be denied the benefits of the Act if the court affirmatively finds that he will not benefit from the more lenient sentencing alternative; 
5. Ex Parte Decision-Making. The Supreme Court reasoned in Kent that "[i] $\mathrm{f}$ a decision on waiver is 'critically important' it is equally of 'critical importance' that the material submitted to the judge . . . be subjected . . . to examination, criticism, and refutation." 52 This rationale is equally persurisive with respect to the materials relied upon in making a similarly "critically important" decision in the federal context, albeit that the decision-maker in the latter situation is an executive rather than a judicial officer. The Court's warning that " $[t]$ here is no irrebuttable presumption of accuracy attached to staff reports" 53 is universally applicable.

Thus, the similarities between the factors found to be determinative in Kent and those involved in the federal juvenile procedure statutes should dictate an extension of the Kent protections-right to hearing and to counsel -to situations in which the Attorney General decides to prosecute a juvenile as an adult. It is suggested here that the constitutional underpinnings of Kcnt are sufficient to demand that extension through judicial construction. Should the courts refuse to act, juvenile rights to due process could be guaranteed by congressional enactment.

To protect any rights thus granted to juvenile defendants some form of review would, of course, be necessary. Otherwise, recognition of the rights could become merely a pro forma exercise. In Cox, the court declined to reach the issue of the reviewability of the Attorney General's decision under the Administrative Procedure Act, ${ }^{54}$ although indicating that judicial review for abuse of discretion is not necessarily precluded. ${ }^{55}$ Holding the Attorney General's decision reviewable, however, adds yet another step to the adjudicatory process which might well impermissibly lengthen the time required for final disposition and add immeasurably to the burdens of administration.

A solution may lie in combining availability of review with a very heavy burden of proof on complainant. This would provide a remedy for instances in which discretion has been exercised in a clearly erroneous manner which, coupled with a well-publicized policy of reversing only on the clearest showing of abuse might discourage the use of review as a delaying tactic or as a matter of course.

In view of the general federal policy of yielding jurisdiction over juveniles to the states, ${ }^{56}$ it is unlikely that limited review would unduly burden the courts. Administrative ease could be further facilitated by the clear ar-

it is possible that the juvenile may not successfully complete the program; and, in any event, juvenile offenders sentenced under this Act are sent, not to rehabilitation centers, as are those proceeded against as juveniles, but rather to special youth offender treatment institutions. See note 6 supra.

52. 383 U.S. at 563 .

53. Id.

54. 5 U.S.C. $\S \S 701$ et seq. (1970).

55. Cox v. United States, 473 F.2d 334, 337 (4th Cir. 1973) (rehearing en banc).

56. See note 7 supra. 
ticulation of standards and principles to be used in making the determination, as was suggested in the policy memorandum attached to the Kent decision. ${ }^{57}$

It is clear that the system that has painstakingly been devised by beneficent legislatures to interpose the mitigating presence of juvenile courts and correction agencies between the youthful offender and the law enforcement system is not working as was originally intended. The rationale for excluding from the juvenile proceeding the full panoply of procedural rights which have been fashioned for the protection of the accused individual was to foster a non-adversary atmosphere in which the best remedial solution could be found. It has developed, however, that the means designed to achieve this purpose are often being used to circumvent the desired ends. The protections finally recognized by Kent as necessary for those subject to a juvenile court's waiver decision are based on considerations so fundamental to our system of due process that they should not be susceptible to evasion simply by a legislative decision to locate the decision-maker in the executive rather than judicial branch. When the discretionary decision of a strategically placed individual can effect such important personal rights, it seems only reasonable that the juvenile's voice should be allowed to be heard in his own defense.

Karen Boxer

57. Sec notes 43-48 supra and accompanying text. 